\title{
Requirements of digestible methionine + cystine for broiler chickens at 1 to 42 days of age
}

\section{Cláudia de Castro Goulart ${ }^{1}$, Fernando Guilherme Perazzo Costa ${ }^{2}$, José Humberto Vilar da Silva ${ }^{3}$, Janete Gouveia de Souza ${ }^{4}$, Valéria Pereira Rodrigues ${ }^{5}$, Cleber Franklin Santos de Oliveira ${ }^{5}$}

\author{
1 Programa de Doutorado Integrado em Zootecnia da UFPB, Areia, PB. Curso de Zootecnia da UVA, Sobral, CE. Bolsista da Funcap. \\ 2 Departamento de Zootecnia da UFPB, Areia, PB. \\ ${ }^{3}$ Departamento de Agropecuária/CCHSA/UFPB, Bananeira, PB. \\ ${ }^{4}$ Departamento de Zootecnia da UFRN, Natal, RN \\ 5 Programa de Pós-graduação em Zootecnia da UFPB, Areia, PB.
}

ABSTRACT - The objective of this work was to estimate requirements of digestible methionine + cystine for broiler chickens from 1 to 42 days of age. It was carried out four experiments for each one of the following phases: pre-initial, initial, growing and final. The birds were distributed in a completely randomized experimental design, with six treatments and six replicates. Treatments consisted of a basal feed for each phase, deficient in digestible methionine + cystine and supplemented with DL-methionine to supply six levels of digestible methionine + cystine, resulting in different digestible methionine + cystine:digestible lysine ratios. In the pre-initial phase, levels of digestible methionine + cystine did not influence feed intake and feed conversion. However, weight gain responded in a quadratic way. In the initial phase, levels of digestible methionine + cystine had decreasing linear effect on feed intake whereas weight gain and feed conversion were influenced in a quadratic manner. In the growth and final phases, feed intake was not influenced by levels of digestible methionine + cystine, but weight gain and feed conversion presented quadratic response. The levels of $0.873 ; 0.755 ; 0.748$ and $0.661 \%$ of digestible methionine + cystine in the diet or the daily intake of $183 ; 575 ; 1,104$ and $1,212 \mathrm{mg}$ of digestible methionine + cystine are recommended for the pre-initial, initial, growth and final phases, respectively, which corresponds to the ratios of $71 ; 70 ; 76$ and $72 \%$ of digestible methionine + cystine to digestible lysine.

Key Words: digestible amino acids, ideal protein, sulfur amino acid

\section{Exigências de metionina + cistina digestível para frangos de corte de 1 a 42 dias de idade}

\footnotetext{
RESUMO - Objetivou-se estimar as exigências de metionina + cistina digestível para frangos de corte machos de 1 a 42 dias de idade. Foram realizados quatro experimentos para cada uma das fases: pré-inicial, inicial, crescimento e final. As aves foram distribuídas em delineamento inteiramente casualizado, com seis tratamentos e seis repetições. Os tratamentos consistiram de uma ração basal para cada fase, deficiente em metionina + cistina e suplementada com DL-metionina para fornecer seis níveis de metionina + cistina digestível, resultando em diferentes relações metionina + cistina digestível:lisina digestível. Na fase pré-inicial, os níveis de metionina + cistina digestível não influenciaram o consumo de ração e a conversão alimentar. No entanto, o ganho de peso respondeu de forma quadrática. Na fase inicial, os níveis de metionina + cistina digestível tiveram efeito linear decrescente sobre o consumo de ração, enquanto o ganho de peso e a conversão alimentar foram influenciados de forma quadrática. Nas fases de crescimento e final, o consumo de ração não foi influenciado pelos níveis de metionina + cistina digestível, porém o ganho de peso e a conversão alimentar apresentaram resposta quadrática. Recomendam-se os níveis de 0,873;0,755;0,748 e $0.661 \%$ de metionina + cistina na dieta ou o consumo diário de 183,575, 1.104 e $1.212 \mathrm{mg}$ de metionina + cistina digestível nas fases préinicial, inicial, crescimento e final, respectivamente, que correspondem às relações de $71,70,76$ e $72 \%$ de metionina + cistina digestível:lisina digestível.
}

Palavras-chave: aminoácidos digestíveis, aminoácidos sulfurados, proteína ideal 


\section{Introduction}

Protein is a key nutrient in poultry nutrition and has a significant share in the cost of the diet formulation, directly influencing feed conversion, carcass quality, and weight gain of animals. However, birds have requirements of amino acid met but not of crude protein (Nascimento, 2004). Thus, a better understanding of the nutritional requirements of individual amino acids allows a more precise nutrition, offering the possibility for the formulator to partially replace the requirement of at least minimum levels of crude protein by essential amino acids requirements, generating lower costs for the producer and lower emissions to the environment (Suida, 2001).

In most situations, the sulfur amino acids methionine and cystine are limiting in diets for commercial broilers (Fatufe \& Rodehutscord, 2005), making it essential to supplement the diet with synthetic methionine for best performance and economic results. According to Al-Mayah (2006), methionine can be economically added in most diets for broilers, which reduces the levels of crude protein and, therefore, the quantities of soybean meal in those diets.

Methionine can be converted irreversibly to cysteine via transulfuration. Therefore, cystine can be considered as a nonessential amino acid, provided that the supply of methionine is appropriate (Pillai, 2005). Thus, the requirements of these amino acids are usually considered together as requirements for methionine + cystine.

Sulfur amino acids are used by broilers in several metabolic functions as primary constituents of structural proteins and protection with regard to the production of antibodies (Albino et al., 1999). Methionine is the most important donor of methyl radical in the body and it is required for the biosynthesis of many important substances involved in growth, such as creatine, carnitine, polyamines, epinephrine, melatonin and choline (Baker et al., 1996). Moran Jr. (1994) reported that the deficiency in methionine reduces weight gain, feed efficiency and protein content in the carcass, and stimulate feed intake when this deficiency is not hard, contributing to additional energy causing an increase in body fat deposition.

Thus, this study was conducted to estimate the digestible methionine + cystine requirements for broilers from 1 to 42 days of age.

\section{Material and Methods}

Four experiments were conducted in Universidade Federal da Paraíba. It was used 2,700 Cobb broiler chicks males, with 900 chicks for the pre-starter (from 1 to 7 days of age) phase, 720 for the initial phase (from 8 to 21 days of age), 540 to the growing phase (from 22 to 35 days of age) and 540 for the final phase (from 36 to 42 days of age), with initial weights of $44.9 \pm 0.6 \mathrm{~g} ; 196.1 \pm 2.5 \mathrm{~g} ; 936.4 \pm 12.3 \mathrm{~g}$ and $2189.0 \pm 31.1 \mathrm{~g}$, respectively. The birds were distributed in a completely randomized design with six treatments, each one with six replications, with 25 chicks per experimental unit in the pre-initial phase, 20 chicks in initial phase and 15 chicks in growing and final phases.

The treatments consisted on a basal diet for each phase (Table 1) formulated to meet the nutritional requirements of broilers according to Rostagno et al. (2005), except for lysine and methionine + cystine. The levels of digestible lysine used in experimental diets $1.234 \%$ for the pre-initial phase; $1.084 \%$ for the initial phase, $0.978 \%$ for growing phase and $0.947 \%$ for the final phase) were determined by the performance of the broilers in previous experiments carried out in the Universidade Federal da Paraíba. The levels of digestible methionine + cystine were: $0.734 ; 0.794$; $0.854 ; 0.914 ; 0.974$ and $1.034 \%$ in the pre-initial phase; $0.604 ; 0.664 ; 0.724 ; 0.784 ; 0.844$ and $0.904 \%$ in the initial phase, $0.563 ; 0.623 ; 0.683 ; 0.743 ; 0.803$ and $0.863 \%$ in the growing phase and $0.522 ; 0.582 ; 0.642 ; 0.702 ; 0.762$ and $0.822 \%$ in the final phases. The variation in digestible methionine + cystine levels was obtained by supplementation of DL-methionine instead of corn starch.

During the pre-initial and initial phases, chicks were housed in type "Brasilia" metal cage, with floor screen, containing feeders and drinkers. The heating of the facility was carried out through an electrical system, with $60-\mathrm{W}$ incandescent lamps until 14 days of age. In the final two phases, the chickens were housed in pens measuring $1.40 \times 1.80 \mathrm{~m}$, with concret floors covered with cane sugar byproduct, and tubular feeders and drinkers.

The birds used in the initial stages of growing and final phases were reared in another facility until the beginning of the experiment when they were then weighed individually and distributed in the experimental treatments. During the pre-experimental phase, chicks were reared in floor covered with sugar cane byproduct, heated by a gas heater and they were fed diets formulated to meet the requirements of each stage (Rostagno et al., 2005) ad libitum. It was used a continuous $(24$ hours of light $=$ natural + artificial $)$ lighting regimen throughout the period (pre-experimental and experimental).

The variables were the following: feed intake (FI), weight gain (WG) and feed conversion (FC), for all phases, and carcass yield, breast, drumstick and thigh weight and relative heart, liver, abdominal fat and gizzards for the final. 
Table 1 - Composition of basal diets

\begin{tabular}{|c|c|c|c|c|}
\hline \multirow[t]{2}{*}{ Ingredient } & \multicolumn{4}{|c|}{ Phase } \\
\hline & Pre-initial & Initial & Growing & Final \\
\hline Corn & 57.563 & 61.530 & 61.650 & 67.002 \\
\hline Corn gluten meal & 4.264 & 4.742 & 0.000 & 0.000 \\
\hline Soybean oil & 2.713 & 3.000 & 2.749 & 1.723 \\
\hline Bicalcium phosphate & 1.939 & 1.812 & 1.627 & 1.480 \\
\hline Salt & 0.464 & 0.446 & 0.415 & 0.391 \\
\hline DL-methionine & 0.106 & 0.000 & 0.020 & 0.009 \\
\hline L-lysine.HCL $78.4 \%$ & 0.388 & 0.323 & 0.059 & 0.144 \\
\hline L-threonine & 0.145 & 0.073 & 0.061 & 0.077 \\
\hline L-arginine & 0.060 & 0.000 & 0.005 & 0.000 \\
\hline Choline chloride $60 \%$ & 0.070 & 0.070 & 0.070 & 0.070 \\
\hline Metabolizable energy (kcal/kg) & 2950 & 3000 & 3100 & 3150 \\
\hline Crude protein $(\%)$ & 22.04 & 20.79 & 19.41 & 18.03 \\
\hline Calcium $(\%)$ & 0.939 & 0.884 & 0.824 & 0.763 \\
\hline Available phosphorus (\%) & 0.470 & 0.442 & 0.411 & 0.380 \\
\hline Digestible lysine $(\%)$ & 1.234 & 1.084 & 0.978 & 0.947 \\
\hline Digestible methionine + cystine $(\%)$ & 0.734 & 0.604 & 0.563 & 0.522 \\
\hline Digestible methionine $(\%)$ & 0.342 & 0.288 & 0.267 & 0.245 \\
\hline Digestible threonine $(\%)$ & 0.865 & 0.745 & 0.697 & 0.661 \\
\hline Sodium $(\%)$ & 0.223 & 0.214 & 0.205 & 0.194 \\
\hline
\end{tabular}

Feed intake was calculated as the difference between the amount of feed supplied and refusals at the end of each experiment. To determine weight gain, the birds were weighed at the beginning and at the end of each phase. Feed conversion was calculated by dividing the total feed intake by weight gain during the period, adjusting the data by weighing the remains of dead birds and feed whenever there was a dead bird.

At 42 days of age, three birds weighing representative of the average weight of the parcel were selected to the slaughter and carcass evaluation. For carcass d etermination, it was considered the weight of the eviscerated carcass in relation to body weight after fasting. The yield of prime cuts was determined by the weight of the eviscerated carcass (with head and feet) whereas the relative weights of organs were calculated in relation to body weight during the fasting period.

The results were statistically analyzed by using the program SAEG-System for Statistical Analysis and Genetics (Universidade Federal de Viçosa, 1999). It was realized regression analysis by using linear and quadratic effects to determine the digestible methionine + cystine requirement.

\section{Results and Discussion}

There was no effect of levels of digestible methionine + cystine on feed intake and feed conversion of chicks in the pre-initial phase. However, weight gain responded quadratically (Table 2), with the greatest estimated gain to the level of $0.873 \%$ digestible methionine + cystine, by the equation $y=-241.84+889.69 x-509.69 x^{2}\left(r^{2}=0.92\right)$ or daily consumption of $183 \mathrm{mg}$ of digestible methionine + cystine per bird.

According to Brugalli (2003), the response of an animal to a limiting nutrient, generally follows the law of diminishing returns. This means that animal performance improvement in a non-linear way with increasing dietary supplementation of the nutrient until the maximum potential growth of the animal, under the management conditions to which it is subjected, is fully expressed and the greatest addition of the nutrient does not promote any additional response performance. For the studied nutrients, the increased levels of digestible methionine + cystine probably promoted greater protein deposition, resulting in greater weight gain. 
Brito et al. (2004), using diets with $20 \% \mathrm{CP}$ and 0.641 and $0.926 \%$ methionine + cystine, or $22 \% \mathrm{CP}$ and 0.705 and $0.926 \%$ methionine + cystine (total) found no difference on weight gain of broiler chicks during 1-7 day-of-age phase. Moreover, Sklan \& Noy (2003) observed maximum body weight and feed efficiency to seven day-of-age chicks fed diets containing $0.91 \%$ methionine + cystine (total). Leandro et al. (2007), assessing levels of methionine ( 0.458 , $0.507,0.559$ and $0.611 \%$ ) at levels of $0.795 ; 0.847 ; 0.900$ and $0.952 \%$ methionine + cystine (total) in pre-starter diets for broiler chicks found no significant answers for feed intake, weight gain and feed conversion, but the best results for weight at 7 days of age were tested at 0.900 and $0.952 \%$ methionine + cystine.

The application of lysine (1.234\%) used in the formulation of experimental diets determined in previous experiment at the Universidade Federal da Paraíba was $93 \%$ out of 91 suggested by Brazilian tables for poultry and swine (Rostagno et al., 2005). The level of digestible methionine + cystine, resulting in better weight gain of chickens was $92.5 \%$ of the tabulated value $(0.944 \%)$. By using this level, the ratio of digestible methionine + cystine to digestible lysine diet was $71 \%$, which is similar to the relationship established by Rostagno et al. (2005) for chickens from 1 to 21 days of age.

However, Andrade (2000), cited by Leandro et al. (2007), using isocaloric and isonitrogenous diets but with different ratios of amino acids, found that body weight, weight gain and feed conversion of broiler chicks in first week of life were significantly improved in birds fed diets with methionine + cystine:lysine of $76 \%$.
In the initial phase, there was a linear effect of digestible methionine + cystine levels on the feed intake (Table 3 ), and for every $0.06 \%$ increase in the amino acid, there is an estimated reduction of $19.1 \mathrm{~g}$ in consumption, by the equation $\mathrm{y}=1307.8-319.32 \times\left(\mathrm{r}^{2}=0.91\right)$.

According to Moran Junior (1994), studies have shown that broilers increase the consumption of food when the diet contains inadequate amounts of methionine. However, in this study, this effect of increased feed intake by birds fed diets with lower levels of digestible methionine + cystine was not found in the initial phase.

Weight gain and feed conversion showed a quadratic response (Table 3$)$. The greatest gain $(770.5 \mathrm{~g} / \mathrm{bird})$ and the best conversion (1.402) were estimated by the levels of 0.711 and $0.755 \%$ digestible methionine + cystine in the diet, respectively, by the equations $y=-465.2+3478.3 x-2447.7 x^{2}$ $\left(r^{2}=0.94\right)$ and $y=3.6582$ to $5.9757 x+3.9571 x^{2}\left(r^{2}=0.99\right)$, corresponding to a daily intake of 549 and $575 \mathrm{mg}$ of digestible methionine + cystine per bird.

The ratio of digestible methionine + cystine to digestible lysine estimated for best feed conversion was $70 \%$, lower than that found in Rostagno et al. (2005), that was $71 \%$. Similarly, in this phase, the application of digestible lysine determined in previous experiment $(1.084 \%$ ) was $95 \%$ of the tabulated $(1.146 \%)$ whereas the value found for digestible methionine + cystine represents $93 \%$ of the tabulated one $(0.814 \%)$. These results demonstrated that, although the amino acid requirements for broilers were lower (on average 93\%) than those recommended by Rostagno et al. (2005), the digestible methionine + cystine to lysine ratio remained almost unchanged, reinforcing the concept of ideal protein

Table 2 - Feed intake, weight gain and feed conversion of broilers, according to digestible methionine + cystine levels in the pre-initial diet

\begin{tabular}{|c|c|c|c|c|c|c|c|c|}
\hline & \multicolumn{6}{|c|}{ Digestible methionine + cystine $(\%)$} & \multirow[t]{2}{*}{ Regression } & \multirow[t]{2}{*}{$\mathrm{CV}(\%)$} \\
\hline & 0.734 & 0.794 & 0.854 & 0.914 & 0.974 & 1.034 & & \\
\hline Feed intake (g/bird) & 146.4 & 157.1 & 148.5 & 151.9 & 138.3 & 138.9 & ns & 3.45 \\
\hline Feed conversion $(\mathrm{g} / \mathrm{g})$ & 1.103 & 1.078 & 1.001 & 1.062 & 1.012 & 1.035 & $\mathrm{~ns}$ & 3.91 \\
\hline
\end{tabular}

Q** - Quadratic effect at $1 \%$ probability; $\mathrm{CV}$ - coefficient of variation; ns - not significant

Table 3 - Feed intake, weight gain and feed conversion of broilers, according to digestible methionine + cystine levels in the initial diet

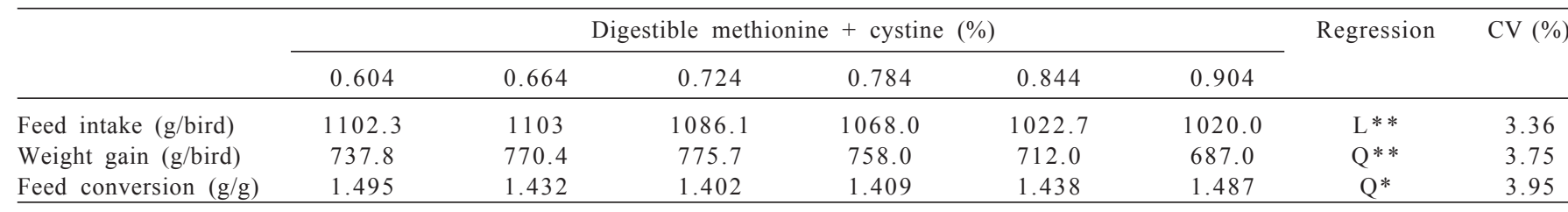

$\mathrm{Q}^{* *}$ - Quadratic effect at $1 \%$ probability; $\mathrm{Q}^{*}$ - quadratic effect at $5 \%$ probability; $\mathrm{L}^{* *}$ - linear effect at $1 \%$ probability; CV - coefficient of variation. 
in which the quantities of amino acids determined in relation to the requirement of lysine.

Feed intake was not influenced by increasing levels of digestible methionine + cystine of the $\operatorname{diet}$ (Table 4$)$. This result was similar to those obtained by Oliveira Neto et al. (2007), who also found no relationship among the levels of sulfur amino acids on the feed intake of broilers in the growing phase. However, Rodrigueiro et al. (2000) found linear effect so feed intake increased with increasing digestible methionine + cystine levels in the diet. Kiraz \& Şengül (2004) evaluated two different diets for male broilers from 35 to 45 days of age, so one was prepared normally with $0.81 \%$ of methionine + cystine whereas the other was deficient in these amino acids, with $0.52 \%$ of methionine + cystine. It was verified that the first symptom of amino acid deficiency in diets was a reduction of appetite in the animals. When adequate feeding was given after methionine-deficient diet, the feed intake values were adjusted to the normal level on the same day.

The variation in results among studies may be related to differences in the level of protein and amino acid profile of diets, among other factors, such as genetics, gender and environment.

There were significant levels of digestible methionine + cystine on weight gain and feed conversion, with estimated levels of 0.748 and $0.758 \%$ digestible methionine + cystine in the $\operatorname{diet}\left(\mathrm{y}=-1742.7+7816.6 \mathrm{x}-5224,5 \mathrm{x}^{2}, \mathrm{r}^{2}=0.99\right.$ and $\mathrm{y}=6.8206$ to $\left.13.394 \mathrm{x}+8.8294 \mathrm{x}^{2}, \mathrm{r}^{2}=0.92\right)$, corresponding to a daily intake of 1,104 and $1,119 \mathrm{mg} / \mathrm{bird}$ for better gain and conversion, respectively. By using the level of digestible methionine + cystine, which resulted in better feed conversion, it was calculated the digestible methionine + cystine to digestible lysine ratio of $76 \%$ in the diet and it was higher than the one recommended by Rostagno et al. (2005) (72\%).
In the final phase, digestible methionine + cystine levels did not affect feed intake, whereas weight gain and feed conversion showed a quadratic response (Table 5), and estimated the optimum levels of 0.661 and $0.667 \%$ in feed, by using equations $y=-1464.1+6623 x-5004 x^{2}$ $\left(r^{2}=0.90\right)$ and $y=7.5165$ to $17.208 x+12.892 x^{2}\left(r^{2}=0.77\right)$, respectively. By using the level of $0.661 \%$ of digestible methionine + cystine, which provided the best weight gain (higher coefficient of determination) and the average feed intake of broilers, it is estimated that daily consumption of $1,212 \mathrm{mg}$ of digestible methionine + cystine per bird is enough for optimal performance. Thus, the digestible methionine + cystine:lysine ratio for this phase is $72 \%$.

In most works found in literature, the methionine + cystine requirements were determined for the period from 22 to 42 days of age (Rodrigueiro et al., 2000; Amarante Júnior et al., 2004; Oliveira Neto et al., 2007).

Rodrigueiro et al. (2000) evaluated the effects of methionine + cystine levels on male broilers performance and observed a quadratic effect on weight gain and feed conversion, estimating the requirement by $0.896 \%$ in growing $\operatorname{diet}$ ( 22 to 42 days of age).

A study by Kalinowski et al. (2003) was carried out to determine the levels of cystine and methionine separately for broilers of fast and slow feathering during the period from 3 to 6 weeks of age. By combining the values methionine and cystine, the requirements for total sulfur amino acids resulting in slow and fast feathering broilers were 0.83 and $0.88 \%$ respectively.

Amarante Júnior et al. (2005), by considering the performance data, estimated $0.823 \%$ of total methionine + cystine for better performance of broilers in the period from 22 to 42 days of age, corresponding to $0.793 \%$ of

Table 4 - Feed intake, weight gain and feed conversion of broilers, according to digestible methionine + cystine levels in the growing diet

\begin{tabular}{|c|c|c|c|c|c|c|c|c|}
\hline & \multicolumn{6}{|c|}{ Digestible methionine + cystine $(\%)$} & \multirow[t]{2}{*}{ Regression } & \multirow[t]{2}{*}{ CV (\%) } \\
\hline & 0.563 & 0.623 & 0.683 & 0.743 & 0.803 & 0.863 & & \\
\hline Feed intake $(\mathrm{g} / \mathrm{bird})$ & 2058.2 & 2131 & 2112.3 & 2001.1 & 2039.2 & 2061.5 & $\mathrm{~ns}$ & 3.23 \\
\hline Feed conversion $(\mathrm{g} / \mathrm{g})$ & 2.051 & 1.938 & 1.832 & 1.692 & 1.741 & 1.860 & $\mathrm{Q}^{* *}$ & 5,54 \\
\hline
\end{tabular}

Q** - Quadratic effect at $1 \%$ probability; CV - coefficient of variation; ns - not significant.

Table 5 - Feed intake, weight gain and feed conversion of broilers, according to digestible methionine + cystine levels in the final diet

\begin{tabular}{|c|c|c|c|c|c|c|c|c|}
\hline & \multicolumn{6}{|c|}{ Digestible methionine + cystine $(\%)$} & \multirow[t]{2}{*}{ Regression } & \multirow[t]{2}{*}{$\mathrm{CV}(\%)$} \\
\hline & 0.522 & 0.582 & 0.642 & 0.702 & 0.762 & 0.822 & & \\
\hline Feed intake (g/bird) & $1,265.4$ & $1,351.5$ & $1,285.4$ & $1,276.1$ & $1,262.9$ & $1,263.1$ & $\mathrm{~ns}$ & 4.94 \\
\hline Weight gain (g/bird) & 631.0 & 682.0 & 754.8 & 724.0 & 652.6 & 610.0 & $\mathrm{Q}^{* *}$ & 5.32 \\
\hline Feed conversion $(\mathrm{g} / \mathrm{g})$ & 2.005 & 1.982 & 1.703 & 1.763 & 1.935 & 2.071 & $\mathrm{Q} * *$ & 5.48 \\
\hline
\end{tabular}

Q** - Quadratic effect at 1\% probability; CV - coefficient of variation; ns - not significant. 
Table 6 - Absolute and relative weights of edible viscera and abdominal fat of broilers at 42 days, according to digestible methionine + cystine levels in the final diet

\begin{tabular}{|c|c|c|c|c|c|c|c|c|}
\hline & \multicolumn{6}{|c|}{ Digestible methionine + cystine $(\%)$} & \multirow[t]{2}{*}{ Regression } & \multirow[t]{2}{*}{ CV $(\%)$} \\
\hline & 0.522 & 0.582 & 0.642 & 0.702 & 0.762 & 0.822 & & \\
\hline \multicolumn{9}{|c|}{ Absolute weight (g) } \\
\hline Carcass & 2204.6 & 2224.7 & 2206.5 & 2233.4 & 2164.9 & 2224.6 & ns & 3.35 \\
\hline Breast & 735.7 & 733.1 & 721.9 & 746.5 & 701.9 & 754.9 & ns & 3.48 \\
\hline Drumstick & 275.7 & 279.3 & 279.7 & 280.6 & 279.6 & 279.1 & ns & 4.74 \\
\hline Thigh & 334.7 & 334.0 & 337.7 & 333.9 & 331.9 & 326.7 & ns & 3.98 \\
\hline Gizzard & 49.5 & 56.6 & 59.9 & 50.5 & 51.3 & 52.2 & ns & 9.79 \\
\hline Heart & 14.1 & 15.3 & 14.5 & 15.0 & 15.1 & 14.4 & ns & 9.22 \\
\hline Liver & 45.6 & 47.4 & 46.7 & 46.8 & 45.9 & 47.4 & ns & 9.71 \\
\hline Abdominal fat & 45.6 & 39.8 & 40.1 & 38.6 & 43.4 & 37.9 & $\mathrm{~ns}$ & 15.44 \\
\hline \multicolumn{9}{|c|}{ Yield/relative weight (\%) } \\
\hline Carcass & 78.7 & 78.5 & 77.8 & 78.9 & 78.5 & 78.9 & $\mathrm{~ns}$ & 1.58 \\
\hline Breast & 33.4 & 33.0 & 32.7 & 33.4 & 32.4 & 33.9 & ns & 2.33 \\
\hline Drumstick & 12.5 & 12.6 & 12.7 & 12.6 & 12.9 & 12.5 & $\mathrm{~ns}$ & 2.91 \\
\hline Thigh & 15.2 & 15.0 & 15.3 & 15.0 & 15.3 & 14.7 & $\mathrm{~ns}$ & 2.94 \\
\hline Gizzard & 1.77 & 2.00 & 2.11 & 1.79 & 1.86 & 1.85 & ns & 9.24 \\
\hline Heart & 0.50 & 0.54 & 0.51 & 0.53 & 0.55 & 0.51 & ns & 8.9 \\
\hline Liver & 1.63 & 1.67 & 1.64 & 1.65 & 1.66 & 1.68 & $\mathrm{~ns}$ & 8.45 \\
\hline Abdominal fat & 1.63 & 1.40 & 1.41 & 1.37 & 1.57 & 1.35 & ns & 15.38 \\
\hline
\end{tabular}

digestible methionine + cystine. Similarly, Oliveira Neto et al. (2007) found a quadratic effect of methionine + cystine levels on feed conversion of broilers at the same age, recommending $0.661 \%$ of digestible methionine + cystine in the diet, which corresponded to the digestible methionine + cystine:digestible lysine ratio of $72 \%$.

There was no effect of levels of digestible methionine + cystine in any of the carcass traits evaluated (Table 6).

In an experiment carried out by Oliveira Neto et al. (2007) to determine the requirement of methionine + cystine for broilers from 22 to 42 days of age kept under thermoneutral environment $\left(23.5^{\circ} \mathrm{C}\right)$, it was verified that the methionine + cystine levels influenced positively drumstick absolute weigh and thigh relative weight. No effect on absolute or relative weight of breast, carcass and abdomen, thigh absolute weight, and drumstick relative weight, or relative and absolute weight of the organs (heart, liver and gizzard) was verified.

One of the factors affecting the quality of carcasses in broilers is the abdominal fat ratio. Excess fattening in chicken carcasses is not desirable because of the consumer preferences, and excess fattening causes some difficulties in slaughtering and it lowers the rate of feed efficiency of broilers.According to Leenstra (1986), the abdominal fat tissue is approximately $2-3 \%$ of the broiler live weight. In the present study, the values of abdominal fat ranged from 1.35 to $1.63 \%$ of live weight fasting.

Kalinowski et al. (2003) reported that supplementation of methionine to meet total sulfur amino acid need has been previously observed to improve breast meat yield with broilers at similar age with optimization occurring at levels exceeding those required for maximum growth performance. According to these authors, the most prominent response of breast meat compared to weight gain when methionine is first limiting can be explained in terms of growth uncomplicated by fat deposition based on the modeling equations of Gous et al. (1999). However, in this study, the effect of increased levels of methionine were not observed.

\section{Conclusions}

It is recommended $0.873 ; 0.755 ; 0.748$ and $0.661 \%$ of digestible methionine + cystine in the diet or the daily intake of $183 ; 575 ; 1,104$ and $1,212 \mathrm{mg}$ of digestible methionine + cystine for the pre-initial, initial, growing and final phases, respectively, resulting in digestible methionine + cystine:digestible lysine ratios of $71 ; 70 ; 76$ and $72 \%$.

\section{Acknowledgments}

CNPq, Ajinomoto Animal Nutrition and Guaraves by financial and logistical support to research.

\section{References}

ALBINO, L.F.T.; SILVA, S.H.M.; VARGAS JÚNIOR, J.G. et al. Níveis de metionina + cistina para frangos de corte de 1 a 21 e 22 a 42 dias de idade. Revista Brasileira de Zootecnia, v.28, n.3, p.519-525, 1999. 
AL-MAYAH, A.A.S. Immune response of broiler chicks to DLmethionine supplementation at different ages. International Journal of Poultry Science, v.5, n.2, p.169-172, 2006.

AMARANTE JÚNIOR, V.S.; COSTA, F.G.P.; BARROS, L.R. et al. Níveis de metionina + cistina para frangos de corte nos períodos de 22 a 42 e de 43 a 49 dias de idade. Revista Brasileira de Zootecnia, v.34, n.4, p.1195-1201, 2005.

BRITO, A.B.; STRINGHINI, J.H.; CAFÉ, M.B. et al. Níveis de metionina + cistina em rações de frangos de corte na fase préinicial (1 - 7 dias). ARS Veterinaria, v.20, n.1, p.9-15, 2004.

BAKER, D.H.; FERNANDEZ, S.R.; WEBEL, D.M. et al. Sulfur amino acid requirement and cystine replacement value of broiler chicks during the period three to six weeks post-hatching. Poultry Science, v.75, n.6, p.737-42, 1996.

BRUGALLI, I. Eficácia relativa das fontes de metionina. Revista Ave World, n.4, p.58-61, 2003

FATUFE, A.A.; RODEHUTSCORD, M. Growth, body composition, and marginal efficiency of methionine utilization are affected by nonessential amino acid nitrogen supplementation in male broiler chicken. Poultry Science, v.84, p.1584-1592, 2005.

GOUS, R.M. Evaluation of the parameters needed to describe the overall growth, the chemical growth, and the growth of feathers and breast muscles of broilers. Poultry Science, v.78, p.812-821, 1999.

KALINOWSKI, A.; MORAN JUNIOR, E.T.; WYATT, E.T. Methionine and cystine requirements of slow- and fast-feathering broiler males from three to six weeks of age. Poultry Science, v.82, p.1428-1437, 2003.

KIRAZ, S.; ŞENGÜL, T. Relationship between abdominal fat and methionine deficiency in broilers. Czechoslovack Journal Animal Science, v.50, n.8, p.362-368, 2005.

LEANDRO, N.S.M.; CUNHA, W.C.P.; CAFÉ, M.B. et al. Desempenho de frangos com diferentes pesos iniciais alimentados com ração pré-inicial suplementada com metionina. Ciência Animal Brasileira, v.8, n.3, p.373-383, 2007.

LEENSTRA, F.R. Effect of age, sex, genotype and environment on fat deposition in broiler chickens - A review. World. Poultry Science Journal, v.42, n.12-25, 1986.
MORAN JUNIOR, E.T. Response of broiler strains differing in body fat to inadequate methionine: live performance and processing yields. Poultry Science, v.73, p.1116-1126, 1994.

NASCIMENTO, A.H. Deposição de proteína na carcaça de frangos de corte. Aveworld, v.2, p.2-3, 2004

OLIVEIRA NETO, A.R.; OLIVEIRA, R.F.O.; DONZELE, J.L. et al. Níveis de metionina + cistina total para frangos de corte de 22 a 42 dias de idade mantidos em ambiente termoneutro. Revista Brasileira de Zootecnia, v.36, n.5, p.1359-1364, 2007.

OLIVEIRA NETO, A.R.; OLIVEIRA, R.F.O.; DONZELE, J.L. et al. Níveis de metionina + cistina para pintos de corte mantidos em ambiente termoneutro Revista Brasileira de Zootecnia, v.34, n.6, p.1956-1962, 2005.

PILLAI, P.B. Growth and homocysteine remethylation in the chicken: impact of age, methionine source and dietary levels of sulfur amino acids and related compounds. 2005. 182f. Dissertation (Doctor of Philosophy) - University of Arkansas, Arkansas.

ROSTAGNO, H.S.; ALBINO, L.F.T.; DONZELE, J.L. et a1 Tabelas brasileiras para aves e suínos: composição de alimentos e exigências nutricionais. 2.ed. Viçosa, MG: UFV/ DZO, 2005. 186p.

RODRIGUEIRO, R.J.B.; ALBINO, L.F.T.; ROSTAGNO, H.S. et al. Exigência de metionina + cistina para frangos de corte na fase de crescimento e acabamento. Revista Brasileira de Zootecnia, v.29, n.2, p.507-517, 2000.

SKLAN, D.; NOY, Y. Crude protein and essential amino acid requirements in chicks during the first week posthatch. British Poultry Science, v.44, n.2, p.266-274, 2003.

SUIDA, D. Formulação por proteína ideal e conseqüências técnicas, econômicas e ambientais. In: SIMPÓSIO INTERNACIONAL DE NUTRIÇÃO ANIMAL: PROTEÍNA IDEAL, ENERGIA LIQUidA E MODELAGEM, 2001, Santa Maria. Anais.. Santa Maria: EMBRAPA, 2001. p.27-43.

UNIVERSIDADE FEDERAL DE VIÇOSA - UFV. SAEG - Sistema de análises estatísticas e genéticas. Versão 8.0.Viçosa, MG: 1999. 59p. (Manual do usuário). 